\title{
Role of food uptake for photosynthesis, growth and survival of the mixotrophic dinoflagellate Dinophysis acuminata
}

\author{
K. Riisgaard* ${ }^{*}$ P. J. Hansen \\ Marine Biological Laboratory, University of Copenhagen, Strandpromenaden 5, 3000 Helsingør, Denmark
}

\begin{abstract}
Dinophysis acuminata is a mixotrophic dinoflagellate frequently causing diarrhetic shellfish poisoning. D. acuminata was isolated from Danish coastal waters and cultivated using the mixotrophic ciliate Mesodinium rubrum as prey. The roles of food uptake and photosynthesis for the growth and survival of $D$. acuminata were studied. The observed maximum growth rate was ca. $0.45 \mathrm{~d}^{-1}$ at an irradiance of $100 \mu \mathrm{mol}$ photons $\mathrm{m}^{-2} \mathrm{~s}^{-1}$ when supplied with well-fed M. rubrum at concentrations $>1000 \mathrm{M}$. rubrum $\mathrm{ml}^{-1}$. The corresponding ingestion rate per $D$. acuminata was about 9 M. rubrum $\mathrm{d}^{-1}$, or $3200 \mathrm{pg} \mathrm{C} \mathrm{d}^{-1}$. Apart from the importance of prey concentration, data revealed that ingestion and growth of $D$. acuminata are, to a certain degree, dependent on the growth rate of its ciliate prey. Photosynthesis was studied in a culture of $D$. acuminata, initially grown at prey saturation (>1000 M. rubrum cells ml ${ }^{-1}$ ) and subsequently allowed to deplete the prey. When the ciliate prey was added, the photosynthetic rate of $D$. acuminata increased from about 7 to $38 \mathrm{pg} \mathrm{C} \mathrm{cell}^{-1} \mathrm{~h}^{-1}$ within the first $2 \mathrm{~d}$. When subsequently subjected to starvation, the photosynthetic activity rapidly decreased to a pre-feeding level, and, without a minimum food uptake, $D$. acuminata was not able to maintain photosynthetic growth. At high prey concentrations, 70 to $90 \%$ of the gross C uptake can be explained by food uptake. However, at low prey concentrations, only 0 to $55 \%$ of the gross C uptake is likely to be derived from food uptake. The data indicate that in natural environments, $D$. acuminata may often be food limited, and, in this situation, photosynthesis may not only be a supplement to the basic nutrition, but rather the primary $\mathrm{C}$ source.
\end{abstract}

KEY WORDS: Dinophysis acuminata - Dinoflagellate - Mixotrophy · Photosynthesis · Growth · Survival $\cdot$ Mesodinium rubrum

\section{INTRODUCTION}

Members of the genus Dinophysis are planktonic thecate dinoflagellates (Dinophysiales, Dinophyceae), frequently found in coastal and oceanic waters throughout the world (Sournia 1986). The attention to Dinophysis spp. greatly increased when a number of species of the genus were linked to the toxin responsible for the syndrome diarrhetic shellfish poisoning (DSP) (Yasumoto et al. 1980, Hallegraeff \& Lucas 1988, Lee et al. 1989), a gastrointestinal illness causing huge economical losses for the mussel industry, especially around Europe and Japan (Yasumoto et al. 1980, Rhodes et al. 2001).
Dinophysis includes heterotrophic, as well as photosynthetic species, but only photosynthetic species have been linked to DSP, and special attention has been focused on these species. Cell densities are usually

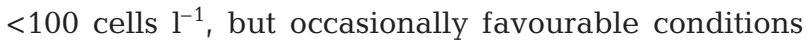
can result in massive blooms with cell densities as high

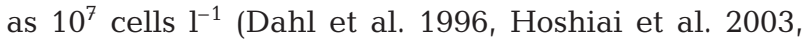
Marcaillou et al. 2005). Although the vast majority of studies on the genus Dinophysis have been related to bloom dynamics, its position in the plankton food web is largely unknown. There are only few existing data on the nutrition of Dinophysis spp., but it is well known that many Dinophysis spp. have an obligate mixotrophic nutritional pattern (i.e. depend on both photo- 
synthesis and food uptake). Ciliates appear to be the preferred food item for heterotrophic, as well as for photosynthetic, Dinophysis spp. (Hansen 1991, Park et al. 2006, Nagai et al. 2008, Nishitani et al. 2008a, b), and so far successful cultures of Dinophysis spp. (i.e. $D$. acuminata, D. caudata, D. infundibulus and D. fortii) have been established by feeding them the photosynthetic ciliate Mesodinium rubrum (=Myrionecta rubra) (Park et al. 2006, Nagai et al. 2008, Nishitani et al. 2008a,b).

Mixotrophy is widespread among dinoflagellates. It is usually a strategy to survive or enhance growth under varying environmental conditions; particularly in periods where light, food, or nutrients are limited (Sanders 1991, Stoecker 1999). Food uptake contributes with major nutrients ( $\mathrm{C}, \mathrm{N}$ and $\mathrm{P}$ ) and/or essential growth factors (vitamins, amino acids and fatty acids). In addition, some heterotrophic protists are able to take up chloroplasts from their prey and use the chloroplasts for photosynthesis during a limited period. This mode of life, known as kleptoplastidy ('stolen plastids'), has been suggested to be a survival strategy for many dinoflagellates, e.g. Gymnodinium acidotum (Fields \& Rhodes 1991), Amphidinium poecilochroum (Larsen 1988, Skovgaard 1998), A. latum (Horiguchi \& Pienaar 1992) and Pfiesteria piscicida (Lewitus et al. 1999). Yet, other dinoflagellates, also lacking their own chloroplasts, harbour more-or-less intact symbionts, which they use for nutrition in various ways, e.g. the green Noctiluca scintillans (Hansen et al. 2004), Durinskia baltica (=Peridinium balticum; Tomas \& Cox 1973, Tomas et al. 1973), Gymnodinium quadrilobum (Horiguchi \& Pienaar 1994) and Kryptoperidinium foliaceum (=P. foliaceum; Jeffrey \& Vesk 1976).

The chloroplasts of Dinophysis spp. and its prey Mesodinium rubrum are characterized by a bright orange fluorescence (ca. 630 to $590 \mathrm{~nm}$ ), when exposed to green excitation light in the epifluorescence microscope (Barber et al. 1969, Lessard \& Swift 1986, Hallegraeff \& Lucas 1988, Schnepf \& Elbrächter 1988). The orange fluorescence is caused by the accessory pigment phycoerythrin (Geider \& Gunter 1989); a pigment usually found in certain cryptophytes (Barber et al. 1969, Wedemayer et al. 1991, Hewes et al. 1998). Based on the spectral colour of the fluorescence, it has been suggested that the chloroplasts of Dinophysis spp. may derive from a cryptophyte, or an organism with a cryptophyte endosymbiont (Schnepf \& Elbrächter 1988). Molecular data support this idea, since the 16 rRNA and $p s b A$ genes of $D$. acuminata and the cryptophyte Teleaulax amphioxia have been found to be alike (Janson \& Granéli 2003, Janson 2004, Minnhagen \& Janson 2006). However, since Dinophysis spp. do not maintain growth when fed with various cryptophytes, including T. amphioxia (Nishitani et al. 2003, Park et al. 2006), it can be rejected that the chloroplast of Dinophysis spp. are kleptochloroplasts acquired directly from cryptophyte prey. Thus, if the Dinophysis spp. chloroplasts are kleptochloroplasts, they must originate from $M$. rubrum. More studies are clearly needed to address this issue, and we will not address it further in the present paper.

The aim of the present study was to provide new information on the role of food uptake for photosynthesis and growth of Dinophysis acuminata isolated from Danish waters. D. acuminata is one of the most common Dinophysis species in European waters and is therefore an appropriate model organism for the genus.

\section{MATERIALS AND METHODS}

Cultures. A culture of the food organism photosynthetic ciliate Mesodinium rubrum was established from single cells isolated from surface seawater samples $\left(16^{\circ} \mathrm{C}, 16 \mathrm{psu}\right)$ collected in Frederikssund, Denmark, during a bloom event on April 17, 2007. Single cells were isolated from the samples using a drawn-out Pasteur micropipette. The isolates were transferred several times to $16 \mathrm{psu}$ sterile-filtered seawater (0.20 $\mathrm{mm}$ Sartorius Minisart filter) before they were placed in multi-dish wells ( 3 cells well ${ }^{-1}$ ), each containing $2 \mathrm{ml}$ of sterile-filtered seawater-based f/20 medium (Guillard 1983) of approximately 16 psu.

The cryptophyte Teleaulax amphioxia (K-0434) was used as a prey species for Mesodinium rubrum and was established from seawater samples collected from the Øresund, Denmark, in March 1990 and provided by the Scandinavian Culture Collection of Algae and Protozoa of the University of Copenhagen. Every 2 to $3 \mathrm{~d}, 1$ drop of diluted $T$. amphioxia suspension in sterile-filtered $f / 20$ medium was added to the wells containing $M$. rubrum. When $M$. rubrum was not able to consume all added T. amphioxia, it was transferred to a new vial containing new sterile-filtered f/20 medium. After 1 mo the wells contained dense suspensions of M. rubrum.

Dinophysis acuminata cultures were established by isolating single cells from surface water samples $\left(18^{\circ} \mathrm{C}\right.$, 22 psu) taken during a bloom event in Hvalpsund, Denmark, on June 16, 2007 (7000 cells $1^{-1}$ ). Approximately 100 cells were isolated using a drawn out micropipette. All cells were transferred several times to sterile-filtered seawater and then transferred to multi-dish wells (ca. 10 cells well ${ }^{-1}$ ) provided with 22 psu sterile-filtered $\mathrm{f} / 20$ medium. Every 2 to $3 \mathrm{~d}$, Mesodinium rubrum was added as prey. One month later, the wells contained dense suspensions of $D$. acuminata. The dinoflagellates were then cultured in 
$65 \mathrm{ml}$ tissue culture flasks with sterile-filtered, $22 \mathrm{psu}$ f/20 medium.

Cultures were incubated on a glass shelf without mixing. Illumination was provided from beneath by cool white fluorescent lamps of $100 \mu \mathrm{mol}$ photons $\mathrm{m}^{-2}$ $\mathrm{s}^{-1}$ following a $14 \mathrm{~h}$ light:10 $\mathrm{h}$ dark cycle. This irradiance was chosen since many dinoflagellate species, including Dinophysis acuminata, have a growth optimum at just about this level (Li et al. 1999, Skovgaard 2000, Kim et al. 2008). Irradiance was measured using a LI-CoRLI-1000 radiation sensor equipped with a spherical probe. The temperature was kept at $20 \pm 1^{\circ} \mathrm{C}$. All cultures were non-axenic.

Experimental conditions. All experimental cultures were maintained in 30 psu seawater-based, sterile-filtered f/2 medium (Guillard 1983) and kept in exponential growth. To ensure this, a fraction of the culture was transferred to newly filtered $f / 2$ medium once a week and supplied with fresh food. Experiments were carried out in $280 \mathrm{ml}$ tissue culture flasks placed on the glass shelf. The experimental conditions were the same as described in the previous paragraph. All experiments were run in triplicate.

pH. Most marine surface waters are considered $\mathrm{pH}$ stable environments with a $\mathrm{pH}$ of ca. 8.1. However, during algal blooms or in dense algae cultures, the $\mathrm{CO}_{2}$ consumption may be so high that $\mathrm{pH}$ is driven far above this otherwise stable value (Hansen 2002). It has been well documented that some microalgae and ciliates are sensitive to extreme $\mathrm{pH}$ values (Hansen 2002, Pedersen \& Hansen 2003) and previous experiments have reported that Mesodinium rubrum becomes growth limited when $\mathrm{pH}$ exceeds 8.5 (Hansen \& Fenchel 2006, Smith \& Hansen 2007). To avoid a potential $\mathrm{pH}$ effect, $\mathrm{pH}$ was measured frequently, and, before $\mathrm{pH}$ exceeded 8.3, the cultures were diluted with fresh medium. $\mathrm{pH}$ was measured directly in the flasks with a hand-held Sentron $\mathrm{pH}$ meter calibrated using standard buffers of pH 7 and 10 .

Growth and grazing. The growth response and grazing properties of Dinophysis acuminata were studied in a number of experiments initiated with different predator:prey ratios (a total of 10 experiments). Growth and ingestion rates of $D$. acuminata were calculated as a function of prey concentration. All experiments were carried out in triplicate, under the same conditions as described above.

To ensure that Mesodinium rubrum approached exponential growth, a dense culture of $M$. rubrum was established prior to the experiments by feeding a culture of $M$. rubrum (ca. 500 cells ml $^{-1}$ ) with Teleaulax amphioxia at a final concentration of ca. 2000 cells $\mathrm{ml}^{-1}$. After $2 \mathrm{~d}$, all prey had been consumed, and $M$. rubrum was transferred into $280 \mathrm{ml}$ tissue culture flasks. Initial predator:prey ratios (Dinophysis acumi- nata $\mathrm{ml}^{-1}: M$. rubrum $\mathrm{ml}^{-1}$ ) were approximately: 40:1500, 60:1900, 34:270, 4:600, 10:600, 35:600, 4:100, $10: 100,35: 100$ and 20:20. A dense culture of D. acuminata acclimated to a low prey concentration $(<100 \mathrm{M}$. rubrum $\mathrm{ml}^{-1}$ ) was added, and the cultures were diluted with sterile-filtered $f / 2$ medium to give the final initial cell concentrations. For controls, 4 replicates of $M$. rubrum without $D$. acuminata were established at the same concentrations as the treatment bottles. Subsamples $(20 \mathrm{ml})$ were then taken every 2 to $3 \mathrm{~d}$. After each measurement, the experimental cultures were filled again with fresh sterile-filtered $f / 2$ medium. Dilution of the cultures was considered in the ingestion and growth rate calculations given below. The duration of each experimental period was 8 to $20 \mathrm{~d}$. The actual predator and prey densities were estimated from 3 to $20 \mathrm{ml}$ sub-samples fixed in $2 \%$ acidic Lugol's solution and counted on an inverted microscope at $100 \times$ magnification. When cell densities were 200 cells $\mathrm{ml}^{-1}$ or more, a $1 \mathrm{ml}$ Sedgewick-Rafter chamber was used for counting. Otherwise 2, 10, or $20 \mathrm{ml}$ sedimentation chambers were used. When using the sedimentation chambers, cells were allowed to settle for at least $2 \mathrm{~h}$. All, or a minimum of 200, cells were counted. The growth rate of $D$. acuminata was estimated as the increase in cell number according to the equation:

$$
\mu_{y}\left(\mathrm{~d}^{-1}\right)=\ln \left(N_{1} / N_{0}\right) / t
$$

where $N_{0}$ and $N_{1}$ are number of cells at time $t_{0}$ and $t_{1}$, respectively, and $t$ is the difference in time between the $t_{0}$ and $t_{1}$ samples.

The ingestion rate, $U$, of Dinophysis acuminata was determined as the reduction in prey concentration in treatment bottles compared to in control bottles, with a monoculture of Mesodinium rubrum. The prey, $x_{\text {, in }}$ the experimental bottles, as well as in the control bottles, were assumed to grow exponentially:

$$
\mu_{x}\left(\mathrm{~d}^{-1}\right)=\ln \left(N_{1} / N_{0}\right) / t
$$

$N_{0}$ and $N_{1}$ are numbers of cells at time $t_{0}$ and $t_{1}$, respectively, and $t$ is the difference in time between the $t_{0}$ and $t_{1}$ samples. The ingestion rate $U_{y}$ was estimated from the following equations:

$$
\begin{gathered}
\frac{d x}{d t}=\mu_{x} x-U_{y} \\
\frac{d y}{d t}=\mu_{y} y
\end{gathered}
$$

where $x$ is the prey ingested by the predator $y$, assuming that the predator $(y)$ grows exponentially at a constant rate of $\mu_{y}$ and that the prey $(x)$ grows at a constant rate of $\mu_{X}$. $U$ is the per capita ingestion rate of $D$. acuminata. $U_{Y}$ is thus the mortality of $M$. rubrum due to predation. From Eqs. (3) \& (4), $U_{y}$ was calculated iteratively by using a simple computer model (Jakobsen \& Hansen 1997). 
Data of Dinophysis acuminata growth (Eq. 5) and ingestion rates (Eq. 6) were fitted to a MichaelisMenten equation:

$$
\mu\left(d^{-1}\right)=\frac{\mu_{\max }\left(x-x_{0}\right)}{K_{m}+\left(x-x_{0}\right)}
$$

where $\mu_{\max }$ is the maximum growth rate of $D$. acuminata $\left(\mathrm{d}^{-1}\right), x$ is the actual prey concentration (Mesodinium rubrum $\mathrm{ml}^{-1}$ ), $x_{0}$ is the threshold prey concentration (where $\mu_{y}=0$ ) and $K_{\mathrm{m}}$ is the prey concentration sustaining one-half $\mu_{\max }$.

$$
U\left(d^{-1}\right)=\frac{U_{\max }(x)}{K_{\mathrm{m}}+x}
$$

where $U_{\max }$ is the maximum ingestion rate per $D$. acuminata $\left(M\right.$. rubrum $\left.\mathrm{d}^{-1}\right), \mathrm{x}$ is the prey concentration (M. rubrum $\mathrm{ml}^{-1}$ ) and $K_{\mathrm{m}}$ is the prey concentration sustaining one-half $U_{\text {max }}$.

Photosynthesis. Photosynthesis was studied in a culture of Dinophysis acuminata initially supplied with replete food (>1000 Mesodinium rubrum $\mathrm{ml}^{-1}$ ) and, subsequently, allowed to deplete the prey. To avoid a potential effect of change in food quality due to starving prey, the experiment was designed in a way so that M. rubrum was depleted within the first few days. The experimental culture was followed for an additional $10 \mathrm{~d}$ after all prey had been consumed. Experimental procedures were the same as in the feeding experiments, but in order to measure photosynthesis from single cells, the initial cell density was increased to $\sim 40$ D. acuminata $\mathrm{ml}^{-1}$ and to $\sim 1500 \mathrm{M}$. rubrum $\mathrm{ml}^{-1}$.

The experiment was carried out in triplicate $280 \mathrm{ml}$ tissue culture flasks under the same conditions as described in the previous section. Triplicate controls of Mesodinium rubrum were established in the same way as in the experimental bottles, with the only exception that Dinophysis acuminata was not added. Then, $20 \mathrm{ml}$ sub-samples were removed every 2 d until all prey were depleted. Thereafter, sub-samples were taken every 3 to $4 \mathrm{~d}$. After each sampling the experimental cultures were refilled with fresh sterile-filtered $\mathrm{f} / 2$ medium. Duration of the experiment was $20 \mathrm{~d}$. Growth and ingestion rates were calculated for each of the treatment cultures as described in the previous section. In addition, cell size was estimated throughout the experiment.

Photosynthetic rates were estimated from a modification of the ${ }^{14} \mathrm{C}$ 'single cell' technique (Rivkin \& Seliger 1981, Skovgaard et al. 2000). Given that Dinophysis acuminata, as well as its prey Mesodinium rubrum, are both photosynthetic organisms, D. acuminata necessarily had to be separated from its prey prior to the photosynthesis measurements. D. acuminata cells were selected from $1 \mathrm{ml}$ of the experimental cultures with a drawn out micropipette. Then, 20 cells were gently rinsed in sterile-filtered $\mathrm{f} / 2$ medium and transferred to $20 \mathrm{ml}$ capacity scintillation vials, each containing $2 \mathrm{ml}$ sterile-filtered $\mathrm{f} / 2$ medium. To ensure that the cells were as healthy as possible, only swimming cells were picked out; dividing cells were not selected. ${ }^{14} \mathrm{C}$-labelled bicarbonate $\left(\mathrm{HCO}_{3}{ }^{-}\right)$was added to the vials at a final radioactive concentration of $1 \mu \mathrm{Ci}$ $\mathrm{ml}^{-1}$, and the vials were incubated in light for $2 \mathrm{~h}$. Light-incubated vials were always accompanied with corresponding dark vials, which were treated similarly to the light vials, except for being wrapped in aluminium foil during incubation. Specific activity of the medium was measured by transferring $100 \mu \mathrm{l}$ from each scintillation vial to new vials each containing $200 \mu \mathrm{l}$ phenylethylamin. Then, $10 \mathrm{ml}$ scintillation cocktail (Packard Insta-Gel, Packard) was added, and the vials were capped (Packard poly-screw caps).

The remaining $1.9 \mathrm{ml}$ of medium was used to measure the amount of fixed ${ }^{14} \mathrm{C}$. To these vials $2.0 \mathrm{ml}$ of $10 \%$ acetic acid in methanol was added, to remove inorganic $\mathrm{C}$. The vials were dried at $60^{\circ} \mathrm{C}$ until the following day, and the residuals were diluted in $2.0 \mathrm{ml}$ distilled water. Subsequently, $10 \mathrm{ml}$ of scintillation cocktail was added. In order to obtain reliable results, vials were mounted with new caps. Activities were determined with a Packard 1500 Tri-Carb liquid scintillation analyzer with automatic quench correction.

Before the ${ }^{14} \mathrm{C}$ single cell method was used, 2 test experiments were performed. Since long exposure of dinoflagellates to ${ }^{14} \mathrm{C}$ may influence estimates of $\mathrm{C}$ content (Rivkin \& Seliger 1981, Skovgaard \& MendenDeuer 2003), Dinophysis acuminata was tested for linear ${ }^{14} \mathrm{C}$ uptake over time: 4 replicate vials with $20{ }^{14} \mathrm{C}$ labelled cells were incubated for 1, 2, 3, 4 and $5 \mathrm{~h}$, and processed as described above. The ${ }^{14} \mathrm{C}$ uptake increased in a linear manner over incubation time, when incubation time was $<5 \mathrm{~h}$ (linear regression: $\mathrm{R}^{2}=$ 0.99; Fig. 1A). An incubation time of $2 \mathrm{~h}$ was used for further experiments.

Photosynthesis, $P$, given as the total amount of inorganic C incorporated per cell (pg cell ${ }^{-1} \mathrm{~h}^{-1}$ ), was calculated as follows:

$$
P=D P M_{\text {cell }} \times D I C /(S A \times t)
$$

where $\mathrm{DPM}_{\text {cell }}$ is DPM (disintegrations per minute) obtained for each cell (corrected for background DPM), SA is the specific activity of the ${ }^{14} \mathrm{C}$-labelled medium (DPM ml ${ }^{-1}$ ) in which cells were labelled, $t$ is the incubation time $(\mathrm{h})$, and DIC is the concentration of dissolved inorganic carbon, which was determined for each replicate with an InfraRed Gas Analyzer Model ADC 225 MK3. A 2 mM NaHCO 3 solution was used as standard. Means were estimated from the average of 3 injections, each of $80 \mu \mathrm{l}$.

In another experiment, we tested whether handling had any negative effects on the photosynthesis of cells. First, $2 \mathrm{ml}$ of a Dinophysis acuminata culture without 

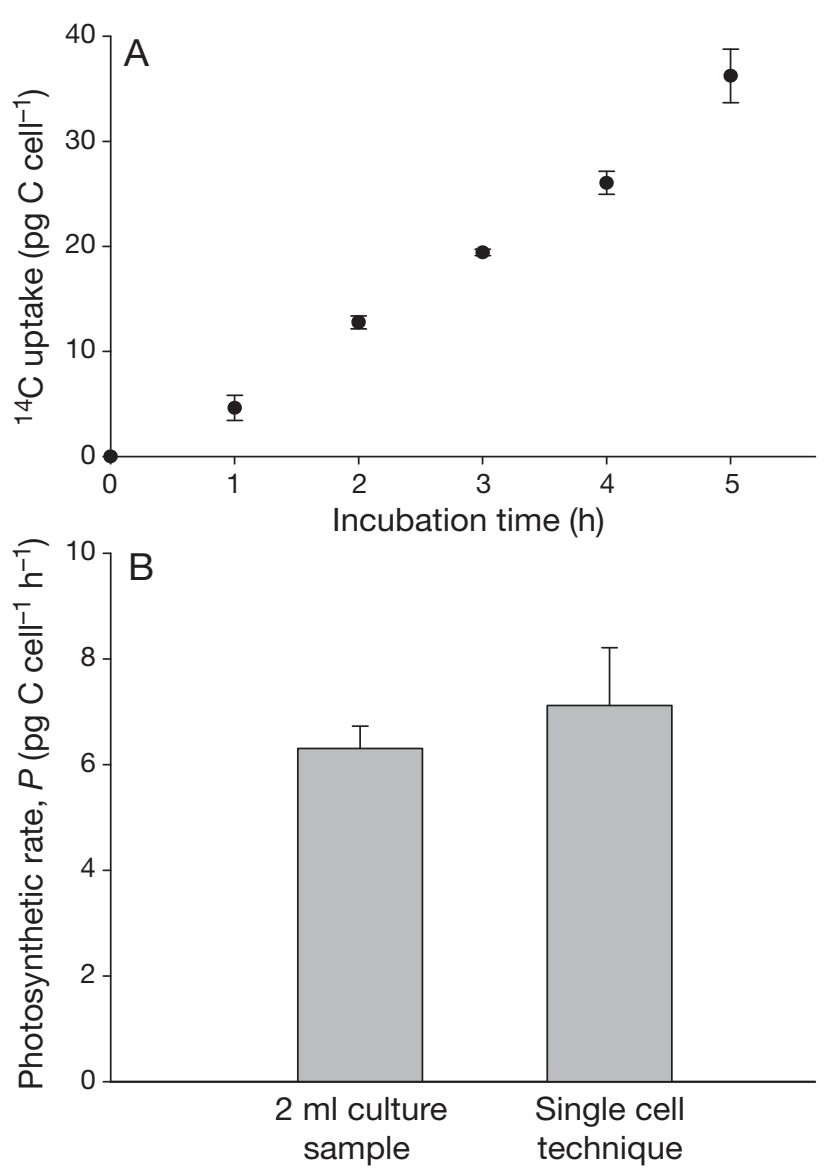

Fig. 1. Dinophysis acuminata. (A) ${ }^{14} \mathrm{C}$ uptake as a function of incubation time (linear regression: $\mathrm{R}^{2}=0.99$ ). (B) Comparison of photosynthetic rates $(P)$ when using different ${ }^{14} \mathrm{C}$ techniques: ${ }^{14} \mathrm{C}$ uptake of filtered culture sample versus isolated cells ( $\mathrm{p}>0.05, t$-test). Bars and data points represent treatment means \pm SE $(\mathrm{n}=4)$

Mesodinium rubrum was carefully transferred to each of 4 replicate scintillation vials by using an automatic pipette. In addition, 20 cells were individually transferred to each of 4 replicate scintillation vials filled with $2 \mathrm{ml}$ sterile-filtered $\mathrm{f} / 2$ medium. The experiment was run in both light and dark and incubated according to the ${ }^{14} \mathrm{C}$ single cell technique as described above. There was no significant difference between $P$ of filtered and of single cells isolated by micropipette ( $t$-test, $\mathrm{p}<0.05$; Fig. 1B).

Functional role of photosynthesis and food uptake. $\mathrm{A}$ new experiment was set up to estimate total gross carbon uptake at 8 different prey concentrations. Estimates were obtained from 2 batch experiments, in which prey concentration changed over time. C uptake was estimated between time points at which prey concentrations were different. Ingestion and photosynthetic rates were estimated as described above. In order to compare heterotrophic C uptake (ingestion) with photosynthetic C uptake, it was assumed that photosynthesis was constant in the time interval between each measurement. Preda- tor:prey ratios (Dinophysis acuminata $\mathrm{ml}^{-1}:$ Mesodinium rubrum $\mathrm{ml}^{-1}$ ) given as average values between measurements were approximately: 100:1500, 50:1400, 100:600, 100:500, 150:150, 150:40 and 100:5. The corresponding growth rate of $M$. rubrum was $>0.2 \mathrm{~d}^{-1}$ for all estimates. Except in the time interval between each measurement ( 2 to $3 \mathrm{~d}$ ), the cells were not further acclimated to the altered prey concentration. Ingestion rates were calculated in according to Eq. (6).

Linear dimensions of Dinophysis acuminata and its prey Mesodinium rubrum were estimated from Lugolfixed cells measured in a Sedgewick-Rafter chamber by using an inverted microscope at $400 \times$ magnification. The cell dimensions were used to estimate plasma volumes of both predators and prey. Plasma volumes of $D$. acuminata and $M$. rubrum were estimated from suitable geometrical forms. For $D$. acuminata a rotational ellipsoid with an elliptic cross-sectional area was used. Cell lengths were measured from the tip of the epitheca to the bottom of the hypotheca. Since it was not possible to estimate the thickness of the D. acuminata cells, thickness $(T)$ was estimated assuming that $T$ equals one-third of the cell width. One-half of the cell width has been given for well-fed cells (Abildgaard 1992), but since the thickness of $D$. acuminata is highly variable between starved and well-fed individuals, one-third was assumed to be more accurate when measuring cells of varying feeding conditions. For $M$. rubrum a rotational ellipsoid with a circular cross-sectional area was used. For each sample, 20 D. acuminata and 20 M. rubrum cells were measured. Carbon content of $D$. acuminata was estimated with the carbon conversion factor for dinoflagellates: pg $\mathrm{C} \mathrm{cell}^{-1}=$ $0.760 \times$ volume $^{0.819}$; for $M$. rubrum, a carbon conversion factor for diverse protists was used: $\mathrm{pg} \mathrm{C} \mathrm{Cell}^{-1}=0.216$ $\times$ volume $^{0.939}$ (Menden-Deuer \& Lessard 2000). Based on these assumptions the C contents of $D$. acuminata and its prey $M$. rubrum were estimated at $895 \pm 66$ and $356 \pm 19$ pg C cell ${ }^{-1}$ (mean $\pm \mathrm{SE}$ ), respectively.

\section{RESULTS}

\section{Growth and grazing}

In most experiments, Dinophysis acuminata had a lag phase of 2 to $4 \mathrm{~d}$ before growth started after being switched from a low to a high prey concentration. Thereafter, $D$. acuminata grew exponentially, but only for a few days. Then, regardless of the prey concentration, growth and ingestion rates declined, even if prey was still present at high concentrations. Fig. 2 shows a typical growth and grazing response of $D$. acuminata (the initial predator:prey ratio was 10:700 cells $\mathrm{ml}^{-1}$ for D. acuminata and Mesodinium rubrum). 

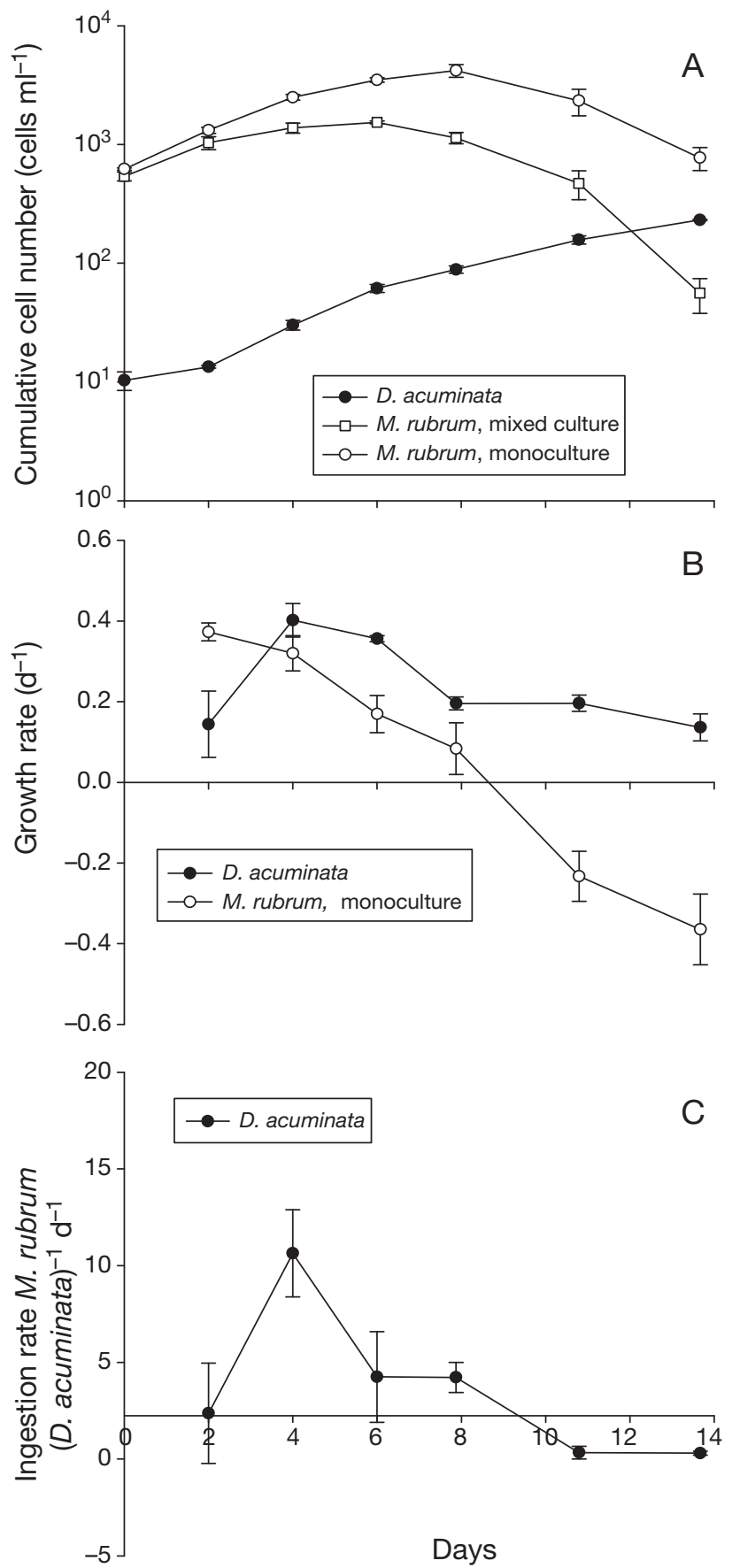

Fig. 2. Dinophysis acuminata, Mesodinium rubrum. Typical development in batch culture growth. (A) Changes in cell numbers of $D$. acuminata and M. rubrum in mixed culture and of $M$. rubrum in monoculture. (B) Growth rate of $D$. acuminata $\left(\mu_{y}\right)$ in mixed culture and $M$. rubrum in monoculture $\left(\mu_{x}\right) \cdot(C)$ Ingestion of $D$. acuminata when fed the ciliate $M$. rubrum.

Data points represent treatment means $\pm \mathrm{SE}(\mathrm{n}=3)$

When cultures of Mesodinium rubrum were grown with replete food and subsequently subjected to starvation, the growth rate was in the range of from 0.3 to $0.5 \mathrm{~d}^{-1}$, but dropped below $0 \mathrm{~d}^{-1}$ after 8 to $10 \mathrm{~d}$ of incuba- tion. Thus, $M$. rubrum was not able to divide $>3$ to 4 times without food, before it slowly died out (Fig. 2). Mortality was measured after ca. 14 to $16 \mathrm{~d}$ of starvation (data not shown, mortality rate, $\mu_{y} \approx-0.04 \pm 0.05 \mathrm{~d}^{-1}$, mean $\pm \mathrm{SE}$ ).

The decreasing growth and ingestion rates of Dinophysis acuminata over time indicated a dependency on the growth rate of Mesodinium rubrum. To explore the role of the prey growth rate (PGR) for the growth and grazing rates of $D$. acuminata, growth and ingestion rates for all 10 experiments were plotted separately in 3 dimensions as a function of PGR in monocultures $\left(\mu_{x}\right)$
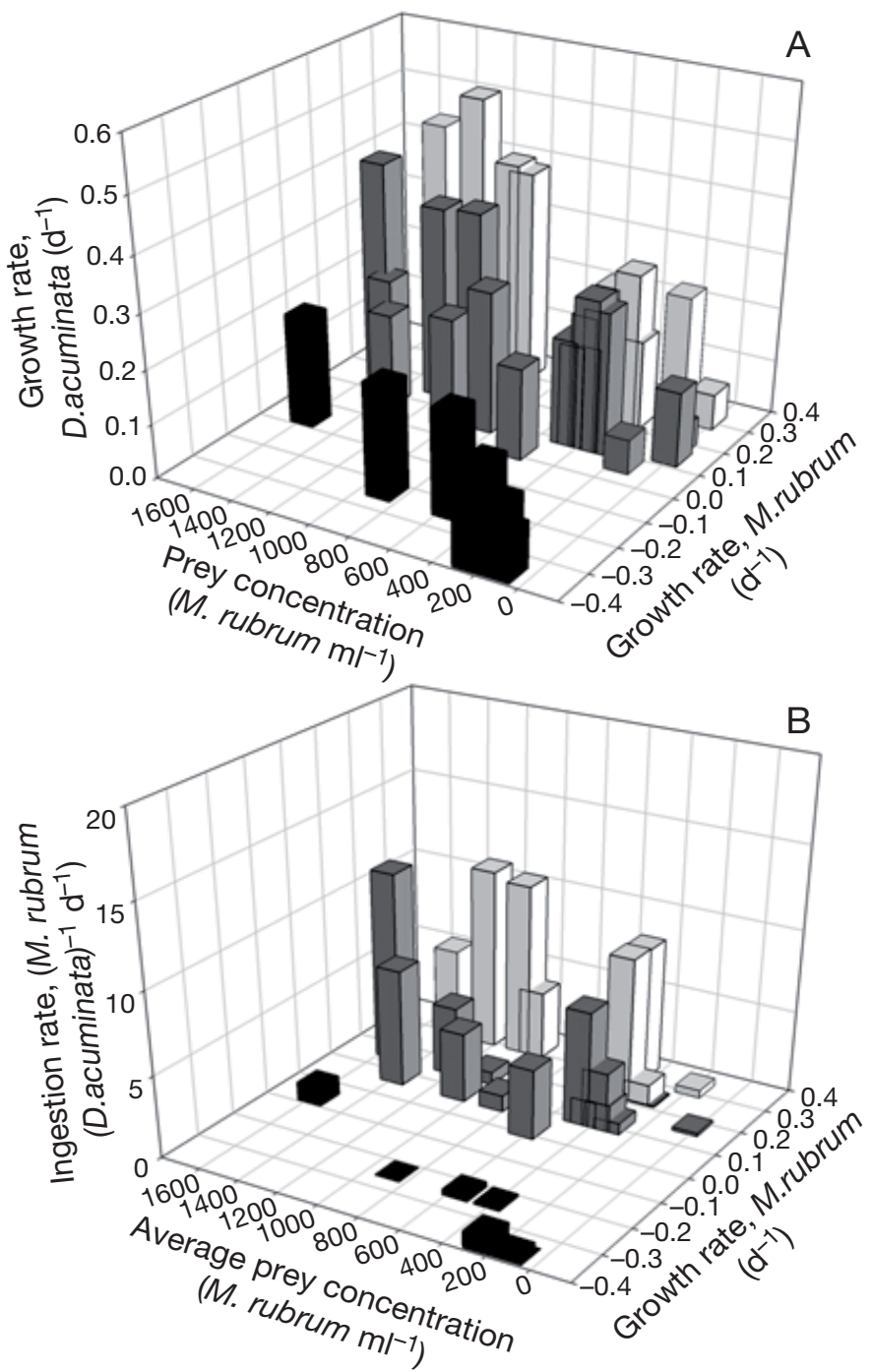

Fig. 3. Dinophysis acuminata, Mesodinium rubrum. Effect of prey concentration $\left(M\right.$. rubrum $\mathrm{ml}^{-1}$ ) and prey growth rate in monoculture $\left(\mathrm{d}^{-1}\right)$ on: (A) growth rate and (B) ingestion rate. To illustrate the effect of prey growth rate (PGR) on growth and ingestion rates, data were subdivided into 3 groups based on the PGR in controls: $>0.2$ to $0.4 \mathrm{~d}^{-1}$ (white bars), 0 to $0.2 \mathrm{~d}^{-1}$ (grey bars) and $<0 \mathrm{~d}^{-1}$ (black bars). Bars represent means of 3 replicates 
and average prey concentration (Fig. 3). The data set shown in the 3D bar charts only includes values from experiments in which $D$. acuminata had been acclimated for 2 to $4 \mathrm{~d}$ (i.e. from the days on which maximum growth was observed; for the sake of clarity, SE bars have been left out of the figures). The 3D bar charts indicate that $D$. acuminata has the highest growth and ingestion rates at high prey concentrations and, further, that the growth and ingestion rates are comparatively smaller when PGR is low. The maximum growth and ingestion rates measured were in the range of from 0.17 to $0.51 \mathrm{~d}^{-1}$ and 1 to $11 M$. rubrum (D. acuminata $)^{-1} \mathrm{~d}^{-1}$, respectively, at prey concentrations $>1000$ cells $\mathrm{ml}^{-1}$. In order to make comparisons with published data possible, growth and ingestion rates were also plotted only as a function of prey concentra-
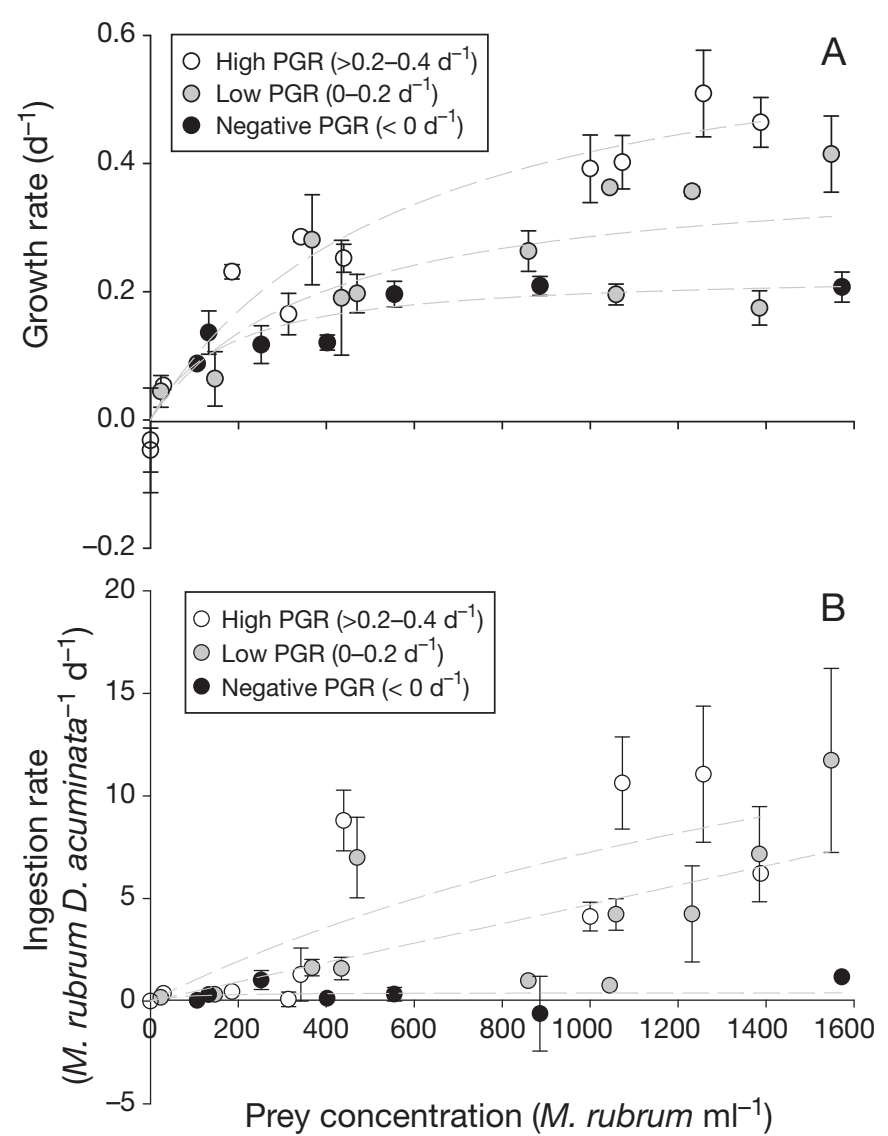

Fig. 4. Dinophysis acuminata, Mesodinium rubrum. (A) Effect of prey concentration $\left(M\right.$. rubrum $\mathrm{ml}^{-1}$ ) on growth rate $\left(\mu_{y}\right)$. (B) Effect of prey concentration ( $M$. rubrum $\mathrm{ml}^{-1}$ ) on ingestion rate. To illustrate the effect of prey growth rate (PGR) on growth and ingestion rates, data were subdivided into 3 groups based on the PGR in controls: $>0.2$ to $0.4 \mathrm{~d}^{-1}$ (high PGR), 0 to $0.2 \mathrm{~d}^{-1}$ (low PGR) and $<0 \mathrm{~d}^{-1}$ (negative PGR). A Michaelis-Menten equation was applied to growth and ingestion data for each of the 3 PGR intervals. D. acuminata was acclimated 2 to $4 \mathrm{~d}$ to the experimental conditions prior to experiments. Data points represent treatment means $\pm \mathrm{SE}(\mathrm{n}=3)$ tion (Fig. 4), still taking the prey growth rate into account. For this purpose, we subdivided the data into 3 groups based on the PGR in the control cultures. The 3 PGR intervals were: $>0.2$ to $0.4 \mathrm{~d}^{-1}$ (high PGR), 0 to $0.2 \mathrm{~d}^{-1}$ (low PGR) and $<0 \mathrm{~d}^{-1}$ (negative PGR). A Michaelis-Menten equation was fitted to data on growth and ingestion rates for each of the 3 intervals (Fig. 4A, B). The growth rate of $D$. acuminata for the high PGR, low PGR and negative PGR intervals closely fit the Michaelis-Menten equation $\left(R^{2}=0.94,0.77\right.$ and 0.90 , respectively). Ingestion rate did not or only moderately fit the equation for the 3 PRG intervals $\left(R^{2}=\right.$ $0.66,0.51$ and 0.04 for the high, low and negative PGR interval, respectively). A comparison of the 3 Michaelis-Menten equations fitted to the PGR intervals revealed that at $>600 \mathrm{M}$. rubrum cells $\mathrm{ml}^{-1}$, the growth rate of $D$. acuminata was generally higher when fed with high PGR prey than when fed with prey of low or negative PGR. For the high PGR interval, a marked reduction in growth rate was observed at prey concentrations $<1000$ cells ml ${ }^{-1}$, but as few as about 50 prey cells $\mathrm{ml}^{-1}$ (ca. $0.5 \mathrm{M}$. rubrum $\mathrm{d}^{-1}$ ) were sufficient to maintain growth of the $D$. acuminata. No notable effect of PGR on ingestion rate appeared between the high and low PGR intervals. However, ingestion rates in the negative PGR interval were markedly smaller than the ingestion rates in the higher PGR intervals (Fig. 4).

\section{Photosynthesis}

Photosynthesis $(P)$ increased from $6.5 \pm 0.6 \mathrm{pg} \mathrm{C}$ cell $^{-1} \mathrm{~h}^{-1}$ to a maximum of $37.9 \pm 5.8 \mathrm{pg} \mathrm{C}$ cell $^{-1} \mathrm{~h}^{-1}$ (mean $\pm \mathrm{SE}$ ), when Mesodinium rubrum was added to the food-limited Dinophysis acuminata culture. This high value was reached on Day 2 at a prey concentration of $1300 \pm 83$ cells ml $^{-1}$ (mean $\pm \mathrm{SE}$ ). Towards Day 6 , when prey were no longer present, $P$ rapidly decreased to a pre-feeding level of $6.6 \pm 0.7 \mathrm{pg} \mathrm{C} \mathrm{cell}^{-1}$ $\mathrm{h}^{-1} . P$ was maintained in the range of from ca. 7 to $14 \mathrm{pg} \mathrm{C}$ cell $^{-1} \mathrm{~h}^{-1}$ for the rest of the experiment (Fig. 5).

The feeding and growth patterns of Dinophysis acuminata determined in this experiment matched the previous feeding experiments, with ingestion rates per $D$. acuminata in the range of from 6 to 8 Mesodinium rubrum $\mathrm{d}^{-1}$ under conditions of high prey concentrations. The lag phase was, however, shorter, and, due to the higher initial predator concentration (ca. 40 cells $\mathrm{ml}^{-1}$ ), the reduction in prey concentration more sudden. During the first $2 \mathrm{~d}$ after initiation of the experiment, D. acuminata grew at a rate of $0.46 \pm 0.04 \mathrm{~d}^{-1}$. Prey were depleted within the first $8 \mathrm{~d}$, and growth was markedly reduced (Fig. 5). By Day 20, the growth rate was close to zero $\left(0.05 \pm 0.04 \mathrm{~d}^{-1}\right.$, mean $\left.\pm \mathrm{SE}\right)$. 

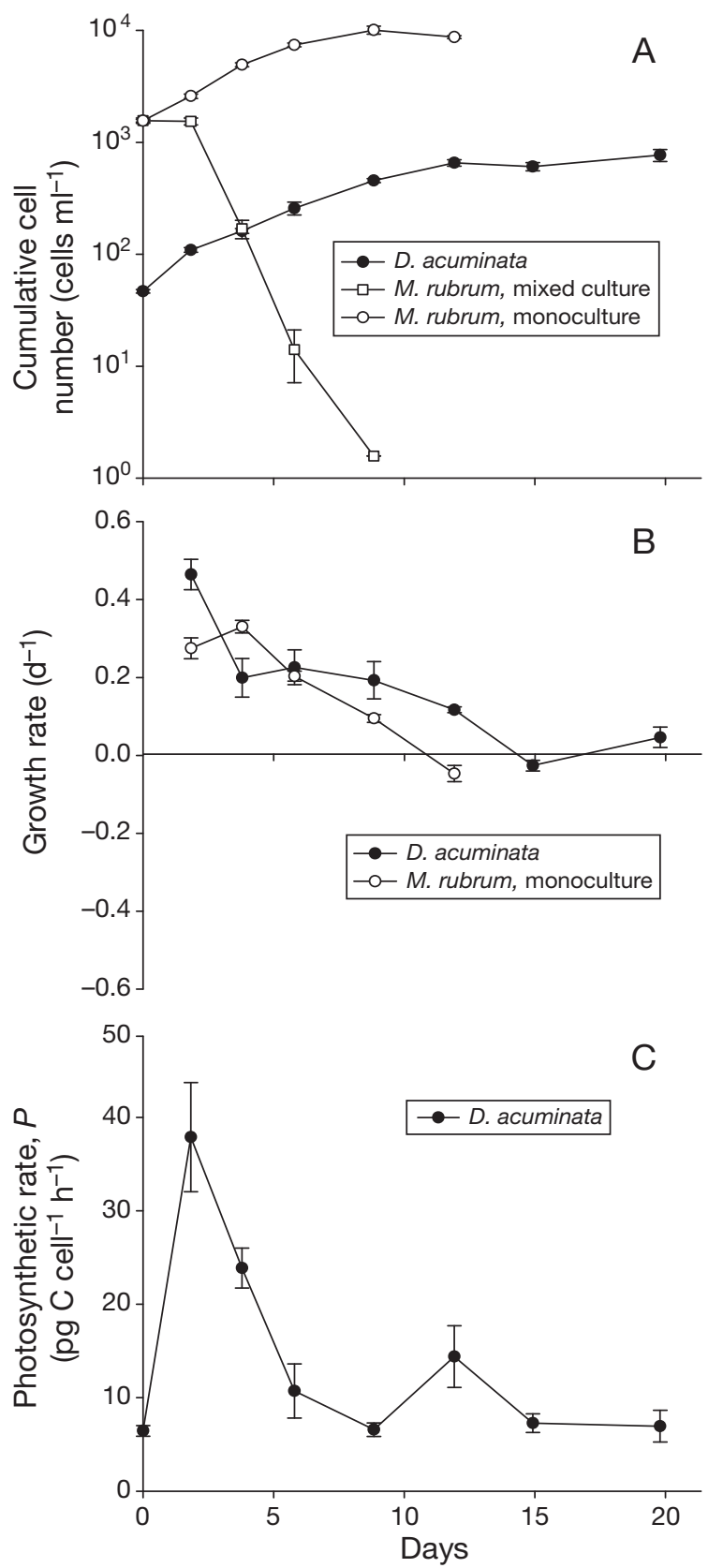

Fig. 5. Dinophysis acuminata, Mesodinium rubrum. (A) Changes in cell numbers of $D$. acuminata and $M$. rubrum in cultures when the ciliate $M$. rubrum is supplied as prey, and changes in cell number of $M$. rubrum grown in monoculture. (B) Growth in cultures initially supplied with $M$. rubrum as prey, and growth of $M$. rubrum in monoculture cultures. (C) Photosynthetic rate, $P\left(\mathrm{pg} \mathrm{C} \mathrm{cell}^{-1} \mathrm{~h}^{-1}\right)$ as a function of time (days). Data points represent treatment means \pm SE $(n=4)$

\section{Functional role of photosynthesis and food uptake}

A new set of experiments was conducted to estimate how much of Dinophysis acuminata's growth was potentially derived from food uptake and how much could have been derived from photosynthesis. Daily gross $\mathrm{C}$ uptake rates obtained through photosynthesis were calculated over the $14 \mathrm{~h}$ light period, while daily gross C uptake gained from food simply reflects daily ingestion rates. Daily gross C uptake rates (obtained through photosynthesis and food, respectively) are plotted as a function of average prey concentration (Fig. 6A-D). The overall $\mathrm{C}$ uptake was highest when prey was plentiful ( $>400$ cells $\mathrm{ml}^{-1}$ ), with total gross $\mathrm{C}$ uptake rates in the range of from 1800 to $2800 \mathrm{pg} \mathrm{C}$ cell $^{-1} \mathrm{~d}^{-1}$. When the prey concentration was $>400$ cells $\mathrm{ml}^{-1}$, ingested prey contributed to 70 to $90 \%$ of the total gross C uptake (Fig. 6D), whereas photosynthesis contributed to the remaining (10 to $30 \%$; Fig. $6 \mathrm{C}$ ). The relative amount that photosynthesis contributed to the total $\mathrm{C}$ uptake increased as prey was consumed. At a prey concentration <200 Mesodinium rubrum $\mathrm{ml}^{-1}$, only 0 to $55 \%$ was obtained through ingested prey (Fig. 6D). The remaining 45 to $100 \%$ was obtained through photosynthesis (Fig. 6C). When D. acuminata was maintained in complete absence of prey, photosynthetic $C$ uptake ranged between 100 and 200 pg C cell ${ }^{-1} \mathrm{~d}^{-1}$ for at least $10 \mathrm{~d}$.

\section{DISCUSSION}

\section{Growth and grazing}

The growth and ingestion rates of Dinophysis acuminata were strongly dependent on the quantity of food. Furthermore, it turned out that the ingestion rates and, consequently, the growth rates of $D$. acuminata were also dependent on the growth rate of the ciliate prey Mesodinium rubrum. The exact reason for this phenomenon is unknown, but it may be related to the ability of $D$. acuminata to detect and catch its prey. $M$. rubrum is a 'jumping ciliate'; it remains motionless for shorter or longer periods interspersed with quick 'jumps'. Observations in the microscope of D. acuminata with both growing and non-growing $M$. rubrum cells showed that the 2 organisms detect and react to each other at a certain distance, implying that they can sense each other mechanically (H. H. Jakobsen \& P. J. Hansen unpubl. data). We did not see any apparent changes in the swimming behaviour of $M$. rubrum in growing and non-growing cultures. However, if $D$. acuminata can use chemical cues to detect its prey, and these chemical cues allow it to detect the ciliate at a greater distance than the ciliate uses to mechanically detect $D$. acuminata, this may explain the results. The hypothesis implies that when $M$. rubrum grows well, it emits more organic substances to be sensed by $D$. acuminata compared to when it does not grow. This is, of course, very speculative, and more research is definitely needed to study this more closely. 


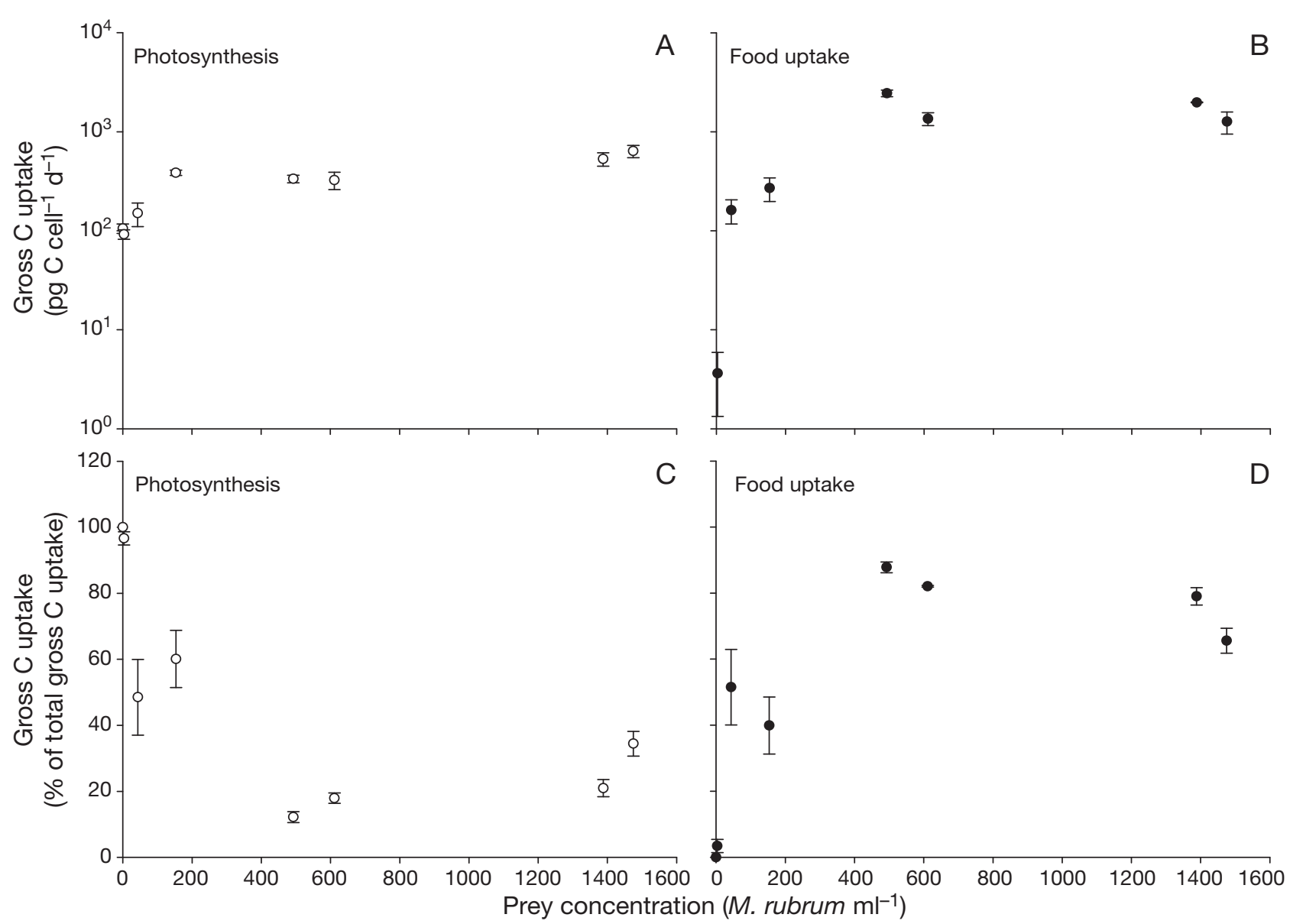

Fig. 6. Dinophysis acuminata, Mesodinium rubrum. Estimated daily C uptake as a function of prey concentration (M. rubrum). (A) Gross photosynthetic $\mathrm{C}$ uptake (pg C cell ${ }^{-1} \mathrm{~d}^{-1}$ ) over the $14 \mathrm{~h}$ light period at an irradiance of $100 \mu \mathrm{mol}$ photons $\mathrm{m}^{-2} \mathrm{~s}^{-1}$. (B) Gross ingested $C$ uptake (pg C cell ${ }^{-1} \mathrm{~d}^{-1}$ ). (C) Percentage of total $C$ uptake (entire gross $C$ uptake from photosynthesis and food) acquired through photosynthesis. (D) Percentage of total $\mathrm{C}$ uptake acquired from food. Data points represent means $\pm \mathrm{SE}(\mathrm{n}=3$ ).

$\mathrm{O}$ : C taken up by photosynthesis; $\bullet$ : C taken up from ingested food

Using only data for which Dinophysis acuminata had been properly acclimated to the actual food concentration and to actively growing prey, the observed maximum growth rates of $D$. acuminata were in the range of 0.39 to $0.51 \mathrm{~d}^{-1}$, when supplied the ciliate Mesodinium rubrum at concentrations $>1000$ cells $\mathrm{ml}^{-1}$. The observed maximum growth rate is comparable to previous in situ estimates of $D$. acuminata from the Baltic Sea: $0.49 \pm 0.05$ to $0.59 \pm 0.13 \mathrm{~d}^{-1}$ (Granéli et al. 1997) and 0.69 to $0.75 \mathrm{~d}^{-1}$ (Gisselson et al. 1999), measured at 10 and $13^{\circ} \mathrm{C}$, respectively. Recently, Kim et al. (2008) found somewhat higher maximum growth rates $\left(0.80 \mathrm{~d}^{-1}\right)$ of a Korean isolate of $D$. acuminata, when cultured at $20^{\circ} \mathrm{C}$ and an irradiance of $60 \mu \mathrm{mol}$ photons $\mathrm{m}^{-2} \mathrm{~s}^{-1}$.

The ingestion rate as a function of prey concentration was much more variable than the growth rate. Some of the variation could be reduced by excluding values where growth rates of Mesodinium rubrum in controls were $<0.20 \mathrm{~d}^{-1}$ (i.e. data from Days 2 and 4 to
6). Using these sorted data, Dinophysis acuminata was found to be an excellent predator, consuming 4 to 11 M. rubrum $\mathrm{d}^{-1}$ (1400 to $3900 \mathrm{pg} \mathrm{C} \mathrm{d}^{-1}$ ) at high prey concentration (>1000 cells ml $\mathrm{m}^{-1}$ ), equivalent to $160-440 \%$ of body $\mathrm{C} \mathrm{d}^{-1}$. Similar results were obtained for the Korean isolate of D. acuminita (Kim et al. 2008). Such specific ingestion rates are of the same order as those found for many strict heterotrophs and a few mixotrophs, which have been estimated to be in the range of from ca. 150 to $350 \%$ of body $\mathrm{C} \mathrm{d}^{-1}$, when cultured under prey saturation, e.g. the heterotrophic dinoflagellate Gymnodinium sp. (Jakobsen \& Hansen 1997), the heterotophic ciliate Balanion comatum (Jakobsen \& Hansen 1997), or the mixotrophic dinoflagellate Karlodinium armiger (Berge et al. 2008). On the other hand, compared to most other mixotrophs, which usually ingest only 10 to $20 \%$ of body $\mathrm{C} \mathrm{d}^{-1}$, the maximum specific ingestion rate is much higher (Bockstahler \& Coats 1993, Caron et al. 1993, Hansen \& Nielsen 1997, Smith \& Hansen 2007). 
Maximum growth and ingestion rates of Dinophysis acuminata were obtained at a relatively high Mesodinium rubrum concentration (>1000 M. rubrum $\mathrm{ml}^{-1}$ ), an observation similar to that by Kim et al. (2008) for the Korean isolate. However, it is noteworthy that $D$. acuminata only needed to ingest approximately $0.5 \mathrm{M}$. rubrum $\mathrm{d}^{-1}$ (177 pg C cell $\mathrm{l}^{-1} \mathrm{~d}^{-1}$ ) to maintain growth. In complete absence of food, growth remained positive for at least 10 to $14 \mathrm{~d}$, and surviving cells were even found after 1 mo of starvation (authors' pers. obs.). This is considerably longer than for protists reported to harbour temporary kleptoplastids/endosymbionts, such as the dinoflagellates Gymnodinium 'gracilentum' (Skovgaard 1998), G. acidotum (Fields \& Rhodes 1991) and Pfiesteria piscicida (Lewitus et al. 1999), or the ciliate Laboea stobila (Stoecker et al. 1988), which are not able to survive for more than ca. 2 to $10 \mathrm{~d}$ without prey.

\section{Photosynthesis}

Unlike most other mixotrophic protists that reduce their photosynthetic activity in food-replete cultures (Sanders et al. 1990, Hansen et al. 2000, Skovgaard et al. 2000, Adolf et al. 2006), Dinophysis acuminata has the highest photosynthetic rates when food is plentiful. A similar pattern has been found in the photosynthetic dinoflagellates Karlodinium micrum (=Gyrodinium galatheanum) (Skovgaard 1998, Li et al. 1999) and Gyrodinium resplendens (Skovgaard 2000). Although the photosynthetic activity of $D$. acuminata varies considerably, the photosynthetic rates obtained here were comparable to those found in most previous studies conducted with natural $D$. acuminata populations incubated under similar light intensities (Granéli et al. 1997). The photosynthetic rate reached a maximum of $38 \pm 6 \mathrm{pg} \mathrm{C}$ cell $^{-1} \mathrm{~h}^{-1}$ at high prey concentrations, but was reduced to ca. 7 pg C cell ${ }^{-1} \mathrm{~h}^{-1}$ as soon as the prey was depleted. These values are equivalent to 83 and $15 \%$ of body $\mathrm{C}$ fixed $\mathrm{d}^{-1}$ for well-fed and starved $D$. acuminata, respectively.

The photosynthetic rates presented here are the first obtained on laboratory cultures of Dinophysis acuminata. The rates were measured for cultures at an irradiance of $100 \mu \mathrm{mol}$ photons $\mathrm{m}^{-2} \mathrm{~s}^{-1}$ and may not represent the maximum rates possible, as photosynthesis might saturate at higher irradiances. In fact, Setälä et al. (2005) showed that in a natural population of $D$. acuminata, photosynthesis saturated between 250 and $500 \mu \mathrm{mol}$ photons $\mathrm{m}^{-2} \mathrm{~s}^{-1}$. At light saturation, Setälä et al. (2005) measured the photosynthetic rates to be in the range of from 160 to $925 \mathrm{pg} \mathrm{C} ~ c e l l^{-1} \mathrm{~h}^{-1}$, which are much higher rates than those found in the present study. Setälä et al. (2005) collected the cells from deep waters (depth from 14 to $80 \mathrm{~m}$ ), where D. acuminata had probably accumulated larger amounts of photosynthetic pigments, due to the lower irradiance found there. As a result, the photosynthetic rates obtained by Setälä et al. (2005) are probably overestimates and may not represent values realistic for cells acclimated to higher light intensities.

\section{Functional role of photosynthesis and food uptake}

The present and other studies (Park et al. 2006, Kim et al. 2008) have revealed the importance of Mesodinium rubrum as a prey for the sustained growth of Dinophysis acuminata. The highest rates of photosynthesis were found when food was plentiful, but the importance of photosynthesis to the overall carbon uptake increased as prey concentration decreased. The contribution of ingested food to gross C uptake was calculated to be 70 to $90 \%$ at high prey concentrations ( $>400$ M. rubrum $\mathrm{ml}^{-1}$ ) and 0 to $55 \%$ at low prey concentrations $\left(<200 \mathrm{M}\right.$. rubrum $\left.\mathrm{ml}^{-1}\right)$. These values are expected to be overestimates, since the entire prey cell is not ingested (see Park et al. 2006).

The balance here between photosynthesis and food uptake at low prey concentration is comparable to that in many mixotrophs, for example, the dinoflagellates Karlodinium micrum (=Gyrodinium galatheanum) (Li et al. 2000, Adolf et al. 2006), Gyrodinium resplendens (Skovgaard 2000) and Noctiluca scintillans (Hansen et al. 2004), and for the freshwater chrysophyte Dinobryon cylindricum (Caron et al. 1993) and the ciliate Mesodinium rubrum (Smith \& Hansen 2007). These species are all primarily phototrophic, but feed under certain circumstances, e.g. under conditions of high prey concentrations or in order to provide either nutrients (Caron et al. 1993, Li et al. 2000) or essential growth factors (Caron et al. 1993, Skovgaard 2000).

\section{Ecological implications}

There have only been a few reports on the natural non-bloom occurrence of Mesodinium rubrum, but cell concentrations in temperate waters are typically in the range of from 0.1 to 10 cells ml ${ }^{-1}$ (Taylor et al. 1971, Lindholm 1985, Montagnes \& Lynn 1989, Nielsen \& Kiørboe 1994). Thus, Dinophysis acuminata seems, in most cases, to be growth limited by prey concentration and, thus, appears to receive a large fraction of its carbon uptake from photosynthesis; that is unless $D$. acuminata has alternative food sources. Even if $D$. acuminata feeds on other ciliates, this would not change the conclusion, because ciliates are typically found at concentrations of 1 to 10 cells ml ${ }^{-1}$ (Lynn \& Montagnes 1991, Nielsen \& Kiørboe 1994, Vaqué et al. 
1997). If, however, D. acuminata feeds on other algae, this may indeed change the conclusion.

Not much is known about the growth rates of Mesodinium rubrum in nature, nor is much known about how such growth rates may influence the ingestion of M. rubrum cells by Dinophysis acuminata. However, since $M$. rubrum does not require the ingestion of more than ca. 1 cryptophyte $\mathrm{d}^{-1}$ in order to maintain growth (Smith \& Hansen 2007) and since this ingestion rate is achieved at natural concentrations of cryptophytes, natural non-bloom populations of $M$. rubrum will most likely be fed upon by $D$. acuminata. However, during red tides of $M$. rubrum, the population may not be growing and thus would not be exploited by D. acuminata. In those cases, $D$. acuminata may become food limited, even though the cell concentrations of $M$. rubrum are very high. Therefore, future studies on the population dynamics of $D$. acuminata should not only take the cell concentration but also the growth condition of $M$. rubrum into account.

Acknowledgements. The present study was supported by funds provided by the Danish Natural Research Council, Projects 272-06-0485 and 2101-07-0084 to P.J.H.

\section{LITERATURE CITED}

Abildgaard H (1992) Plankton i de indre danske farvande. Havforskning Miljøstyrelsen 11:22

Adolf JE, Stoecker DK, Harding LW Jr (2006) The balance of autotrophy and heterotrophy and heterotrophy during mixotrophic growth of Karlodinium micrum (Dinophyceae). J Plankton Res 28:737-751

Barber RT, Whites AW, Siegelman HW (1969) Evidence for a cryptomonad symbiont in the ciliate, Cyclotrichium meunieri. J Phycol 5:86-88

Berge T, Hansen PJ, Moestrup Ø (2008) Prey size spectrum and bioenergetics of the mixotrophic dinoflagellate Karlodinium armiger. Aquat Microb Ecol 50:289-299

Bockstahler KR, Coats DW (1993) Grazing of the mixotrophic dinoflagellate Gymnodinium sanguineum on ciliate populations of Chesapeake Bay. Mar Biol 116:477-487

Caron DA, Sanders RW, Lim EL, Marrasé C and others (1993) Light-dependent phagotrophy in the freshwater mixotrophic crysophyte Dinobryon cylindricum. Microb Ecol 25:93-111

Dahl E, Aune T, Aase B (1996) Reddish water due to mass occurrence of Dinophysis spp. In: Yasumoto T, Oshima Y, Fukuyo Y (eds) Harmful algal blooms. Intergovernmental Oceanographic Commission of UNESCO, Paris, p 265-267

Fields SD, Rhodes RG (1991) Ingestion and retention of Chroomonas spp. (Cryptophyceae) by Gymnodinium acidotum (Dinophyceae). J Phycol 27:525-529

Geider RJ, Gunter PA (1989) Evidence for the presence of phycoerythrin in Dinophysis norvegica, a pink dinoflagellate. Br Phycol J 24:195-198

Gisselson L, Granéli E, Carlsson P (1999) Using cell cycle analysis to estimate in situ growth rate of the dinoflagellate Dinophysis acuminata: drawbacks of the DNA quantification method. Mar Ecol Prog Ser 184:55-62

Granéli E, Anderson DM, Carlsson P, Maestrini SY (1997)
Light and dark carbon uptake by Dinophysis species in comparison to other photosynthetic and heterotrophic dinoflagellates. Aquat Microb Ecol 13:177-186

Guillard RRL (1983) Culture of the phytoplankton for feeding invertebrate animals. In: Berg CJ (ed) Culture of marine invertebrates. Hutchinson Ross, Stroudsberg, PA, p 123-128

Hallegraeff GM, Lucas IAN (1988) The marine dinoflagellate genus Dinophysis (Dinophyceae): photosynthetic, neritic and non-photosynthetic, oceanic species. Phycologia 27: 25-42

Hansen PJ (1991) Dinophysis - a planktonic dinoflagellate genus which can act both as a prey and a predator of a ciliate. Mar Ecol Prog Ser 69:201-204

Hansen PJ (2002) Effect of high pH on the growth and survival of marine phytoplankton: implications for species succession. Aquat Microb Ecol 28:279-288

Hansen PJ, Fenchel T (2006) The bloom-forming ciliate Mesodinium rubrum harbours a single permanent endosymbiont. Mar Biol Res 2:169-177

Hansen PJ, Nielsen TG (1997) Mixotrophic feeding of Fragilidium subglobosum (Dinophyceae) on three species of Ceratium: effects of prey concentration, prey species and light intensity. Mar Ecol Prog Ser 147:187-196

> Hansen PJ, Skovgaard A, Glud RN, Stoecker DK (2000) Physiology of the mixotrophic dinoflagellate Fragilidium subglosum. II. Effects of time scale and prey concentration on photosynthetic performance. Mar Ecol Prog Ser 201: $137-146$

> Hansen PJ, Miranda L, Azanza R (2004) Green Noctiluca scintillans: a dinoflagellate with its own greenhouse. Mar Ecol Prog Ser 275:79-87

Hewes CD, Mitchell BG, Moisan TA, Vernet M, Reid FMH (1998) The phycobilin signatures of chloroplasts from three dinoflagellate species: a microanalytical study of Dinophysis caudata, D. fortii, and D. acuminata (Dinophysiales, Dinophyceae). J Phycol 34:945-951

Horiguchi T, Pienaar RN (1992) Amphidinium latum Lebour (Dinophyseae), a sand-dwelling dinoflagellate feeding on cryptomonads. Jap J Phycol 40:353-363

> Horiguchi T, Pienaar RN (1994) Ultrastructure of a sand dwelling dinoflagellate, Gymnodinium quadrilobum sp. nov. (Dinophyceae) with special reference to its endosymbiotic algae. Eur J Phycol 29:237-245

> Hoshiai GI, Suzuki T, Kamiyama T, Yamasaki M, Ichimi K (2003) Water temperature and salinity during the occurrence of Dinophysis fortii and D. acuminata in Kesennuma Bay, northern Japan. Fish Sci 69:1303-1305

Jakobsen HH, Hansen PJ (1997) Prey size selection, grazing and growth response of the small heterotrophic dinoflagellate Gymnodinium sp. and the ciliate Balanioncomatum-a comparative study. Mar Ecol Prog Ser 158: $75-86$

Janson S (2004) Molecular evidence that the plastids in the toxin producing dinoflagellate genus Dinophysis originate from the free living Teleaulax amphioxia. Environ Microbiol 6:1102-1106

Janson S, Granéli E (2003) Genetic analysis of the psbA gene from single cells indicates a cryptomonad origin of the plastid in Dinophysis (Dinophyceae). Phycologia 42: $473-477$

Jeffrey S, Vesk M (1976) Further evidence for a membranebound endosymbiont within the dinoflagellate Peridinium foliaceum. J Phycol 12:450-455

Kim S, Kang YG, Kim HS, Yih W, Coats DW, Park MG (2008) Growth and grazing responses of the mixotrophic dinoflagellate Dinophysis acuminata as functions of light inten- 
sity and prey concentration. Aquat Microb Ecol 51: $301-310$

Larsen J (1988) An ultrastructural study of Amphidnium poecilochroum (Dinophyceae), a phagotrophic dinoflagellate feeding on small species of cryptophytes. Phycologia 27: 366-377

> Lee JS, Igarashi T, Fraga S, Dahl E, Hovgaard P, Yasumoto T (1989) Determination of diarrhetic shellfish toxins in various dinoflagellate species. J Appl Phycol 1:147-152

Lessard EJ, Swift E (1986) Dinoflagellates for the North Atlantic classified as phototrophic or heterotrophic by epifluorescence microscopy. J Plankton Res 8:1209-1215

Lewitus AJ, Glasgow HB, Burkholder? (1999) Kleptoplastidy in the toxic dinoflagellate Pfesteria piscida (Dinophyseae). J Phycol 35:303-312

Li A, Stoecker DK, Adolf JE (1999) Feeding, pigmentation, photosynthesis and growth of the mixotrophic dinoflagellate Gyrodinium gala theanurn. Aquat Microb Ecol 19: 163-176

Li A, Stoecker DK, Coats DW (2000) Mixotrophy in Gyrodinium galatheatum (Dinophyseae): grazing responses to light intensity and inorganic nutrients. J Phycol 36:33-45

Lynn DH, Montagnes DJS (1991) Global production of heterotrophic marine planktonic ciliates. In: Reid PC, Turley CM, Burkill PH (eds) Protozoa and their role in marine processes. NATO Adv Sci Inst 1 25:281-307

Marcaillou C, Mondeguer F, Gentien P (2005) Contribution to toxicity assessment of Dinophysis acuminata (Dinophyceae). J Appl Phycol 17:155-160

Menden-Deuer S, Lessard EJ (2000) Carbon to volume relationships for dinoflagellates, diatoms and other protist plankton. Limnol Oceanogr 45:569-579

Minnhagen S, Janson S (2006) Genetic analyses of Dinophysis spp. support kleptoplastidy. FEMS Microbiol Ecol 57: $47-54$

Montagnes DJS, Lynn DH (1989) The annual cycle of Mesodinium rubrum in the waters surrounding the Islas of Shoals, Gulf of Maine. J Plankton Res 11:193-201

Nagai S, Nishitani G, Tomaru Y, Sakiyama S (2008) Predation by the toxic dinoflagellate Dinophysis fortii on the ciliate Myonecta rubra and observation of sequestration of the ciliate chloroplasts. J Phycol 44:909-922

Nielsen TG, Kiørboe T (1994) Regulation of zooplankton biomass and production in a temperate, coastal ecosystem. 2. Ciliates. Limnol Oceanogr 39:508-519

Nishitani G, Miyamura K, Imai I (2003) Trying to cultivation of Dinophysis caudata (Dinophyceae) and the appearance of small cells. Plankton Biol Ecol 50:31-36

Nishitani G, Nagai S, Sakiyama S, Kamiyama T (2008a) Successful cultivation of the toxic dinoflagellate Dinophysis caudata (Dinophyceae). Plankton Benthos Res 3:78-85

> Nishitani G, Nagai S, Takano Y, Sakiyama S, Baba K, Kamiyama T (2008b) Growth characteristics and phylogenetic analysis of the marine dinoflagellate Dinophysis infundibulus (Dinophyceae). Aquat Microb Ecol 52: 209-221

Park MG, Kim S, Kim HS, Myung G, Kang YG, Yih W (2006) First successful culture of the marine dinoflagellate Dinophysis acuminata. Aquat Microb Ecol 45:101-106

Pedersen MF, Hansen PJ (2003) Effects of high pH on a natural marine planktonic community. Mar Ecol Prog Ser 260:19-31

Rhodes LL, Mackenzie AL, Kaspar HF, Todd KE (2001) Harmful algae and mariculture in New Zealand. ICES J Mar Sci
58:398-403

Rivkin RB, Seliger HH (1981) Liquid scintillation counting for ${ }^{14} \mathrm{C}$ uptake of single algal cells isolated from natural populations. Limnol Oceanogr 26:780-781

Sanders RW (1991) Mixotrophic protists in marine and freshwater ecosystems. J Eukaryot Microbiol 38:76-81

Sanders RW, Porter KG, Caron DA (1990) Relationship between phototrophy and phagotrophy in the mixotrophic chrysophyte Poterioochromonas malhamensis. Microb Ecol 19:97-109

Schnepf E, Elbrächter M (1988) Cryptophycean-like double membrane-bound chloroplast in the dinoflagellate Dinophysis Ehrenberg: evolutionary, phylogenetic and toxicological implications. Bot Acta 101:196-203

Setälä O, Autio R, Kuosa H, Rintala J, Ylöstalo P (2005) Survival and photosynthetic activity of different Dinophysis acuminata populations in the northern Baltic Sea. Harmful Algae 4: 337-350

Skovgaard A (1998) Role of chloroplast retention in a marine dinoflagellate. Aquat Microb Ecol 15:293-301

Skovgaard A (2000) A phagotrophically derivable growth factor in the plastidic dinoflagellate Gyrodinium resplendens (Dinophyceae). J Phycol 36:1069-1078

Skovgaard A, Menden-Deuer S (2003) Long term exposure of dinoflagellates to ${ }^{14}$ carbon: effects on growth rate and measurements of carbon content. J Plankton Res 25: 1005-1009

Skovgaard A, Hansen PJ, Stoecker DK (2000) Physiology of the mixotrophic dinoflagellate Fragilidium subglosum. I. Effects of phagotrophy and irradiance on photosynthesis and carbon content. Mar Ecol Prog Ser 201:129-136

Smith M, Hansen PJ (2007) Interaction between Mesodinium rubrum and its prey: importance of prey concentration, irradiance and pH. Mar Ecol Prog Ser 338:61-70

Sournia A (1986) Cyanophycees, Dictyophycees, Dinophycees, Rhaphidophycees. In: Sournia A (ed) Atlas du phytoplankton marin, Vol 1. CNRS, Paris

Stoecker DK (1999) Mixotrophy among dinoflagellates, Vol 1. J Eukaryot Microbiol 46:397-401

Stoecker DK, Silver MW, Michelis AE, Dais LH (1988) Obligate mixotrophy in Laboea strobila, a ciliate which retains chloroplasts. Mar Biol 99:415-423

Taylor FJR, Blackbourn DJ, Blackbourn J (1971) Red water ciliate Mesodinium rubrum and its 'incomplete symbionts': a review including new ultrastructual observations. J Fish Res Board Can 28:391-407

Tomas RN, Cox ER (1973) Observations on the symbiosis of Peridinium balticam and its intracellular alga. I. Ultrastructure. J Phycol 9:304-323

Tomas RN, Cox ER, Steidinger KA (1973) Peridinium balticum (Levander) Lemmermann, an unusual dinoflagellate with a mesocaryotic and eukaryotic nucleus. J Phycol 9:91-98

Vaqué D, Bloughl HA, Duarte CM (1997) Dynamics of ciliate abundance, biomass and community composition in an oligotrophic coastal environment (NW Mediterranean). Aquat Microb Ecol 12:71-83

> Wedemayer GJ, Wemmer DE, Glazer AN (1991) Phycobilins of cryptophycean algae-structures of novel bilins with acryloyl substituents from phycoerythrin 566. J Biol Chem 266:4731-4741

Yasumoto T, Oshima Y, Sugawara W, Fukuyo Y, Oguri H, Igarashi T, Fujita N (1980) Identification of Dinophysis fortii as the causative organism of diarrhetic shellfish poisoning. Nippon Suisan Gakkai Shi 46:1405-1411

Submitted: August 12, 2008; Accepted: January 30, 2009

Proofs received from author(s): March 31, 2009 